\title{
PENGEMBANGAN BUKU AJAR FISIKA BERBASIS PROBLEM BASED LEARNING (PBL) PADA MATERI ELASTISITAS DAN HUKUM HOOKE
}

\author{
Dwi Putri Harefa ${ }^{1}$, Ovilia Putri Utami Gumay ${ }^{2}$ \\ dwiputri.0197@gmail.com
}

\author{
${ }^{1,2}$ Program Studi Pendidikan Fisika STKIP PGRI Lubuklinggau, Sumatera Selatan, Indonesia
}

Accepted: 16 Juni 2021

\begin{abstract}
This study aims to develop a Problem Based Learning Physics Textbook on the subject of Elasticity and Hooke's Law that is valid, and practical. The problems in this study are 1) How is the quality of Physics textbooks based on Problem Based Learning if viewed in terms of validity, and practicality, in class XI SMA Negeri 2 Lubuklinggau? 2) How to design and develop a Problem Based Learning-based physics textbook that meets the objectives of validity, and practicality, in class XI of SMA Negeri 2 Lubuklinggau?. The subjects in this study were class XI MIA 2 which consisted of 9 students who were taken by purposive sampling technique. The development model in this study refers to the development model of Sugiyono which consists of 1.Potential and problems, 2.Data collection, 3.Product design, 4.Design validation, 5.Design revision, 6.Product trial, 7.Product revision, 8.Usage trial, 9.Product revision, 10.Mass production. But in this research, only used 9 stages of development. Data was collected by using a student response questionnaire technique. And validation consists of 3 expert validations, material validation with an assessment of 42 in the very good category, language validation with an assessment of 18 in the good category, and media validation with an assessment of 28 in the good category. The validation carried out got results with an assessment of 88 in the good category. Student responses to the physics module based on Problem Based Learning with an assessment of 330 in the very good category. So it can be said that the Problem Based Learning-based physics textbook that has been developed is valid, and practical.
\end{abstract}

Keywords : Textbooks, PBL, Research and Development

Abstrak: Penelitian ini bertujuan untuk mengembangkan Buku Ajar Fisika Berbasis Problem Based Learning pada pokok bahasan Elastisitas dan Hukum Hooke yang valid, dan praktis. Masalah dalam penelitian ini adalah 1)Bagaimana kualitas buku ajar Fisika berbasis Problem Based Learning jika ditinjau dari segi kevalidan, dan kepraktisan, pada kelas XI SMA Negeri 2 Lubuklinggau? 2)Bagaimana mendesain dan mengembangkan buku ajar fisika berbasis Problem Based Learning yang memenuhi sasaran kevalidan, dan kepraktisan, pada kelas XI SMA Negeri 2 Lubuklinggau?. Subjek dalam penelitian ini adalah kelas XI MIA 2 yang terdiri dari 9 siswa yang diambil dengan teknik purposive sampling. Model pengembangan dalam penelitian ini mengacu terhadap model pengembangan dari sugiyono yang terdiri dari 1. Potensi dan masalah, 2.Pengumpulan data, 3.Desain produk, 4.Validasi desain, 5.Revisi desain, 6.Uji coba produk, 7.Revisi produk, 8.Uji coba pemakaian, 9.Revisi produk, 10.Produksi massal. Tetapi dalam penelitiannya hanya menggunakan 9 tahapan pengembangan saja. Pengumpulan data dilakukan dengan teknik angket respon siswa. Dan validasi terdiri dari 3 validasi ahli, validasi materi dengan penilaian 42 dalam kategori sangat baik, validasi bahasa dengan penilaian 18 dalam kategori baik, dan validasi media dengan penilaian 28 dalam kategori baik. Validasi yang dilakukan mendapatkan hasil dengan penilaian 88 dalam kategori baik. Respon siswa terhadap modul fisika berbasis Problem Based Learning dengan penilaian 330 dalam kategori sangat baik. Sehingga dapat dikatakan bahwa Buku Ajar fisika berbasis Problem Based Learning yang dikembangkan telah valid, dan praktis.

Kata kunci : Buku Ajar, PBL, Research and Development 


\section{PENDAHULUAN}

Negara indonesia saat ini berkembang sangat baik dan pesat. Banyak cara untuk memajukan bangsa indonesia dari berbagai sektor. Salah satunya dari sektor pendidikan. Pendidikan merupakan hal yang sangat penting karena dengan adanya pendidikan akan menghasilkan output atau tenaga-tenaga yang berkualitas dan dapat memajukan bangsa indonesia. Oleh karena itu pemerintah Indonesia selalu berupaya meningkatkan mutu pendidikan di Indonesia. Seiring dengan hal tersebut berbagai upaya telah dilakukan oleh Kemendiknas untuk mewujudkan kualitas dan mutu pendidikan yang lebih baik. Salah satu upaya yang dilakukan oleh Kemendiknas adalah pengembangan kurikulum. Kemendiknas selalu melakukan pengembangan kurikulum sesuai dengan tuntutan zaman, dari kurikulum 1947 hingga kurikulum 2013 (K13) yang selalu direvisi sampai sekarang. Dalam kurikulum 2013 (K13), peserta didik dituntut untuk lebih aktif dalam proses pembelajaran dan guru hanya berperan sebagai fasilitator dan motivator (Lorenza, Y., Sasmita, P. R., \& Amalia, S, 2019).

Kurikulum di Indonesia saat ini yang diberlakukan oleh pemerintah adalah kurikulum 2013. Tingkat SD, SMP, SMA dan sederajat hamper sebagian besar sudah menggunakan K13.Terdapat lima pendekatan pengalaman belajar dalam K13 yaitu: mengamati, menanya,mengumpulkan informasi, mengasosiasikan dan mengkomunikasikan (Permendikbud,2014). Kurikulum K13 tidak hanya menekankan pada keterampilan berfikir tingkat rendah/Lower Order Thingking Skill(LOTS), tetapi juga keterampilan berfikir tingkat tinggi/Higher Order Thingking Skill (HOTS) (Komariah, N., Mujasam, M., Yusuf, I., \& Widyaningsih, S. W, 2019).

Proses pembelajaran Ilmu Pengetahuan Alam (IPA) termasuk fisika mestinya menekankan pada pemberian pengalaman langsung kepada siswa sehingga siswa memperoleh pemahaman mendalamtentang alam sekitar dan prospek pengembangan lebih lanjut dapat menerapkannya di dalam kehidupan kehidupan sehari-hari. Pembelajaran IPA di sekolah seharusnya melibatkan aspek sikap, proses, produk, dan aplikasi, sehingga siswa dapat mengalamiproses pembelajaran secara utuh, memahami fenomena alam melalui kegiatan pemecahan masalah, metode ilmiah, dan meniru kerja ilmuan dalam menemukan fakta baru (Ariani, T., \& Suanti, W, 2016). Fisika merupakan salah satu cabang IPA yang mempelajari benda-benda di alam secara fisik dan dituliskan secara matematis agar dapat dimengerti oleh manusia dan dimanfaatkan untuk kesejahteraan umat manusia (Sujanem dkk, 2012). 
Berdasarkan hal tersebut maka pembelajaran fisika tidak lepas dari penguasaan konsep, menerapkannya dalam penyelesaian masalah fisika, dan bekerja secara ilmiah. Namun, pembelajaran fisika dalam kelas saat ini cenderung menekankan pada penguasaan konsep dan mengesampingkan kemampuan pemecahan masalah fisika siswa (Hoellwarth, C., Moelter, M. J., \& Knight, R. D, 2005). Kemampuan pemecahan masalah sangat dibutuhkan siswa dalam pembelajaran fisika. Hal ini dikarenakan aktivitas pemecahan masalah dapat membantu siswa untuk mengkonstruksi pengetahuan baru dan memfasilitasi pembelajaran fisika. Dalam menghadapi tantangan abad ke-21, guru lebih baik mempersiapkan siswa untuk menjadi seorang penyelidik, pemecah masalah, berpikiran kritis dan kreatif (Aji, S., Hudha, M. N., \& Rismawati, A, 2017).

Berdasarkan studi pendahuluan yang telah dilakukan pada tanggal 12 Desember 2019 menggunakan teknik wawancara dengan guru Fisika dan siswa kelas XI MIA SMA Negeri 2 Lubuklinggau didapatkan hasil bahwa SMA Negeri 2 Lubuklinggau menggunakan kurikulum 2013 revisi 2018. Dengan menggunakan kurikulum terbaru sebagian besar siswa masih mengalami kesulitan dalam menjalankan kurikulum 2013. Dalam kurikulum 2013 menggunakan model pembelajaran Problem Based Learning dalam proses KBM. Sebagian besar siswa di kelas kesulitan saat menerapkan model pembelajaran Problem Based Learning kedalam proses KBM diantaranya materi yang belum dipahami oleh siswa ialah elastisitas dan hukum hooke, inilah yang menyebabkan rendahnya pemahaman siswa terhadap konsep yang ada dalam materi, hal tersebut membuat siswa mengikuti proses belajar belum optimal.

Siswa juga menuturkan bahwa mereka lebih suka belajar dengan menggunakan metode praktikum dibandingkan belajar. Banyak faktor yang mempengaruhi hal tersebut misalnya cara penyampaian materi oleh guru yang monoton, tidak menarik, pembelajaran hanya mengandalkan buku paket atau dari penerbit sebagai sumber belajar, kurangya lembar kerja siswa, serta kurangnya peralatan praktikum (Aryansi, D., \& Yolanda, Y. (2020). Siswa mengharapkan sebuah buku ajar yang memiliki tampilan menarik dan tidak membosankan serta terdapat motivasi belajar Fisika. Dari wawancara didapatkan pula bahwa buku ajar yang digunakan masih kurang. Buku ajar yang digunakan masih mengandalkan buku paket atau buku dari penerbit. Di dalam buku paket tersebut kurang mendukung dengan model pembelajaran yang digunakan untuk kurikulum 2013 sekarang. Dalam buku paket tersebut LKP yang disediakan belum lengkap karena hanya terdapat satu LKP. Sedangkan dalam kurikulum 2013 siswa dituntut agar lebih aktif dengan menggunakan model pembelajaran Problem Based Learning. Berdasarkan latar belakang permasalahan 
yang telah dikemukakan di atas, penulis tertarik untuk melakukan penelitian dengan judul "Pengembangan Bahan ajar Fisika Berbasis Problem Based Learning Pada Materi Elastisitas dan Hukum Hooke". Tujuan dari dilakukannya penelitian ini adalah: 1)Untuk mengetahui kualitas buku ajar Fisika berbasis Problem Based Learning jika ditinjau dari segi kevalidan, dan kepraktisan, pada kelas XI SMA Negeri 2 Lubuklinggau?, 2)Untuk mengetahui cara mendesain dan mengembangkan buku ajar fisika berbasis Problem Based Learning yang memenuhi sasaran kevalidan, dan kepraktisan, pada kelas XI SMA Negeri 2 Lubuklinggau.

\section{LANDASAN TEORI}

Sugiyono (2012) menyatakan bahwa metode penelitian dan pengembangan adalah metode penelitian yang digunakan untuk menghasilkan produk tertentu, dan menguji kepraktisan produk tersebut. Setyosari (2013) menjelaskan bahwa penelitian pengembangan adalah kajian secara sistematik untuk merancang, mengembangkan, dan mengevaluasi program-program, proses, dan hasil pembelajaran yang harus memenuhi kriteria dan kepraktisan secara internal. Berdasarkan penjelasan beberapa ahli diatas maka dapat disimpulkan bahwa penelitian pengembangan atau research and development adalah sebuah penelitian dengan kajian secara sistematik yang meneliti dan mengembangkan suatu produk tertentu sesuai dengan kebutuhan yang ada dan harus memenuhi kriteria dan kepraktisan secara internal.

Dalam penelitian pengembangan terdapat banyak model pengembangan yang dikemukakan oleh ahli untuk dipakai pada saat melakukan penelitian pengembangan. Setiap model pengembangan yang dikemukakan memiliki tahapan-tahapannya sendiri. Model penelitian pengembangan yang dikemukakan para ahli antara lain model dick and carey, model 4D, model Sugiyono, model Kemp, serta model Borg and Gall.

Dalam penelitian ini akan menggunakan model penelitian pengembangan milik Sugiyono. Model pengembangan Sugiyono ini dipilih karena dalam langkah penelitiannya terdapat uji coba berlapis atau berulang sehingga kita dapat melakukan uji coba dengan maksimal. Selain itu dalam penelitian Sugiyono revisi produk yang dikembangkan terdapat 2 tahapan jadi kita dapat melakukan revisi dengan baik dan benar sesuai saran dari validator dan juga subjek penelitian. Model pengembangan Sugiyono merupakan model pengembanagan yang memiliki langkah-langkah sederhana dan mudah dilaksanakan dalam penelitian. Sugiyono (2012) mengemukakan langkah-langkah penelitian dan pengembangan dalam sepuluh langkah yaitu: Potensi dan masalah, Pengumpulan data, Desain produk, 
Validasi desain, Revisi desain, Ujicoba produk, Revisi produk, Ujicoba pemakaian, Revisi produk, Produksi massal.

Adapun bagan langkah-langkah penelitian berdasarkan model Sugiyono seperti ditunjukkan pada gambar berikut:

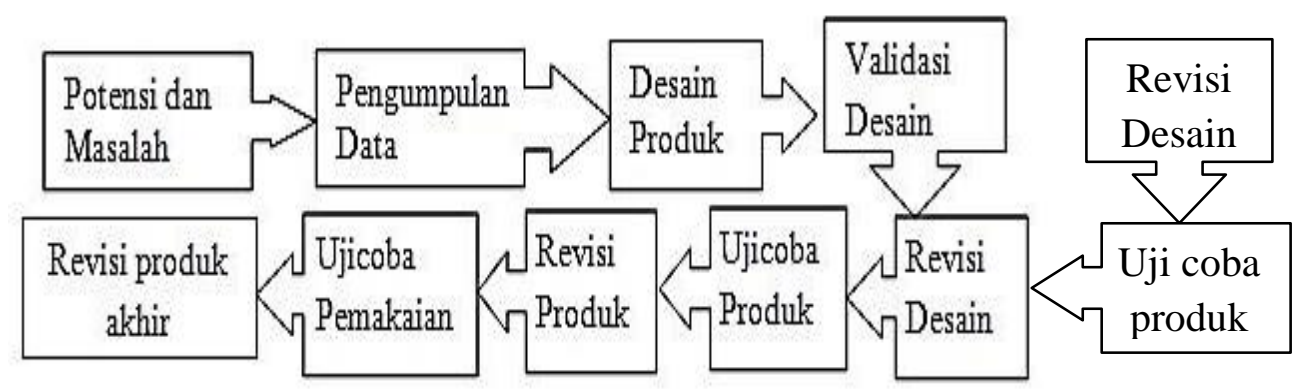

Gambar 1. Model Pengembangan Perangkat Pembelajaran Model Sugiyono (Sugiyono, 2012)

\section{a. Buku Ajar}

Prastowo (2014) mendefinisikan bahan ajar adalah seperangkat materi yang disusun secara sistematis, baik tertulis maupun tidak, sehingga tercipta lingkungan atau susasana yang memungkinkan peserta didik untuk belajar. Sukerni (2014) menjelaskan buku ajar dapat menuntut pembelajaran agar aktif dalam pembelajaran melalui pemberian materi yang disertai dengan gambar yang sangat berkaitan dengan kehidupan siswa, tugas mandiri yang dapat dikerjakan secara individu atau kelompok setiap materi, ringkasan materi setiap bab dan tes akhir bab. Jadi dapat disimpulkan bahwa buku ajar adalah buku yang dipakai untuk mempelajari atau mendalami suatu subjek pengetahuan dan ilmu serta teknologi yang dapat menuntut pembelajaran agar aktif dalam pembelajara yang disusun berdasarkan standar nasional pendidikan.

Dalam penelitian ini buku ajar yang dikembangkan berbasis Problem Based Learning. artinya buku ajar yang dikembangkan menggunakan tahap-tahap dari Problem Based Learning untuk struktur dalam buku ajar. Buku ajar cetak memiliki kelebihan yaitu praktis dibawa kemana-mana, ringan, dan cepat mudah diakses. Namun buku ajar tetap memiliki kekurangan yaitu tidak mampu mempresentasikan gerak dan sulit memberikan bimbingan.

\section{b. Model Pembelajaran Problem Based Learning (PBL)}

Model pembelajaran PBL adalah model pembelajaran yang memberdayakan peserta didik untuk melakukan penyeledikan, memadukan teori dan praktik, serta menerapkan pengetahuan dan keterampilan untuk mengembangkan sebuah solusi praktis atas suatu problem tertentu. model pembelajaran PBL dapat disebut pembelajaran yang berbasis Puplished at https://ojs.stkippgri-lubuklinggau.ac.id/index.php/SJPIF 
masalah merupakan salah satu jenis model pembelajaran yang bersifat Learner Centered atau pembelajaran yang berpusat pada siswa, di samping Project-Based Learning, CaseBased pemberian materi yang disertai dengan gambar yang sangat berkaitan dengan kehidupan siswa, tugas mandiri yang dapat dikerjakan secara individu atau kelompok setiap materi, ringkasan materi setiap bab dan tes akhir bab (Julian, dkk, 2016).

Berdasarkan pendapat beberapa ahli di atas dapat disimpulkan bahwa model pembelajaran Problem Based Learning adalah model pembelajaran yang merujuk pada teknik-teknik investigasi atas fenomena atau gejala untuk mendapatkan pengetahuan baru dan pembelajaran yang berorientasi pada siswa. Model pembelajaran Problem Based Learning memiliki 5 tahapan di dalamnya. Tahapan tersebut yaitu: Mengorientasi, mengorganisasi, membimbing, mengembangkan, dan mengevaluasi.

\section{METODE PENELITIAN}

Dalam penelitian ini untuk mengembangkan sebuah bahan ajar berbasis Problem Based Learning pada materi elastisitas dan hukum hooke menggunakan model pengembangan Sugiyono. Dimana dalam penelitian ini mengadaptasi 9 langkah dari 10 langkah milik Sugiyono. Adapun langkah dari pengembangan model Sugiyono terdapat 10 tahapan yaitu: tahap potensi dan masalah, pengumpulan data, desain produk, validasi desain, revisi desain, uji coba produk, revisi produk, uji coba pemakaian, revisi produk dan produksi massal, namun peneliti hanya menggunakan 9 tahapan yaitu sampai revisi produk. Teknik pengumpulan data dalam penelitian ini menggunakan angket, wawancara dan tes. Adapun instrumen yang digunakan untuk melihat kelayakan dan keefektifan buku ajar yang dikembangkan yaitu menggunakan, angket kevalidan, angket kepraktisan, wawancara dan soal tes.

Buku ajar dikembangkan menggunakan ms word, photoshop, dan photoscape. Buku ajar draf final ini adalah buku ajar yang akan digunakan dalam penelitian di SMA Negeri 2 Lubuklinggau Dimana hasil dari desain yang dilakukan oleh peneliti harus melalui tahap. agar produk yang dikembangkan semakin baik sebelum produk tersebut akan divalidasi oleh para validator yang ahli di bidangnya masing-masing. Validator yang akan memvalidasi buku ajar yang dikembangkan adalah ahli materi oleh bapak Yaspin Yolanda, M.Pd.Si tata bahasa dilakukan oleh ibu Dr. Rusmana Dewi, M.Pd serta ahli media dilakukan oleh Dr. Dodik Mulyono, M.Pd. 
Peneliti melakukan 2 tahap pengujian yaitu dengan menggunakan uji kelompok terbatas dan main field testing, Pada uji kelompok terbatas peneliti menggunakan lembar angket respon siswa dengan 6 orang siswa kelas XII MIA 1, Angket ini berisi 10 pernyataan yang harus diberikan tanggapan oleh siswa. Pada akhirnya tahap uji coba main field testing dilakukan di kelas XI MIA 2 SMAN 2 Lubuklinggau dengan menggunakan angket respon siswa dan 10 soal uji kompetensi sebagai instrumen pengujian kepraktisan produk. Untuk menghitung skor angket menggunakan rumus:

$$
\overline{\mathrm{x}}=\frac{\Sigma x}{n}
$$

keterangan: $\quad \overline{\mathrm{x}}$ : skor rata-rata

(Sumber Sudjana, 2017)

$\Sigma \mathrm{x}$ : jumlah skor

$\mathrm{n} \quad$ : jumlah penilai

Tabel 1. konversi skor aktual menjadi nilai skala 5

\begin{tabular}{cccc}
\hline No & Rentang Skor & Nilai & Kategori \\
\hline 1 & $\mathrm{X}>\bar{x}+1,80 \mathrm{Sbi}$ & $\mathrm{A}$ & Sangat Baik \\
\hline 2 & $\bar{x}+0,60 \mathrm{SBi}<\mathrm{X} \leq \bar{x}+1,80 \mathrm{Sbi}$ & $\mathrm{B}$ & Baik \\
\hline 3 & $\bar{x}-0,60 \mathrm{SBi}<\mathrm{X} \leq \bar{x}+0,60$ Sbi & $\mathrm{C}$ & Cukup Baik \\
\hline 4 & $\bar{x}-1,80 \mathrm{SBi}<\mathrm{X} \leq \bar{x}-0,60$ Sbi & $\mathrm{D}$ & Kurang Baik \\
\hline 5 & $\mathrm{X} \leq \bar{x}-1,80 \mathrm{Sbi}$ & $\mathrm{E}$ & Sangat Kurang Baik \\
\hline
\end{tabular}

\section{HASIL DAN PEMBAHASAN}

Penelitian ini menghasilkan buku ajar yang telah dikembangkan melalui tahapan validasi ahli (kelayakan) dan analisis kepraktisan. Pada penelitian ini dipilih 1 pokok bahasan materi, materi yang dipilih untuk pengembangan buku ajar berbasis PBL ini adalah elastisitas dan hukum hooke. Pembelajaran akan dilaksanakan dua kali dalam 1 minggu. Dalam satu pertemuan dengan waktu 2 x 45 menit dalam satu hari maka sebisa mungkin guru memanfaatkan waktu yang diberikan agar bisa mencapai keterlaksanaan pembelajaran yang maksimal. Peneliti mengambil 1 materi saja karena mengingat adanya keterbatasan waktu dan biaya penelitian. Serta dimaksudkan untuk membantu mempermudah siswa dalam memahami materi yang diajarkan. Buku ajar yang akan dikembangkan akan didesain dengan menggunakan program photoshop, photoschape, dan ms word. Buku ajar yang dikembangkan didesain semenarik mungkin dengan tampilan yang menarik dan perpaduan warna yang dapat menarik perhatian siswa untuk belajar. Selain itu dalam buku ajar nantinya akan mengunakan beberapa tambahan gambar kartun dan gambar yang sesuai dengan materi yang digunakan. 
Gambar digunakan untuk membuat siswa lebih paham dengan materi dan membuat siswa tidak jenuh dan bosan dalam membaca buku.

Buku ajar ini dibuat dengan 2 macam yaitu buku ajar bagi guru dan buku ajar bagi siswa. Buku guru didalamnya memuat materi, Lembar Kerja Praktikum (LKP), contoh soal dan pembahasannya, soal latihan dan pembahannya, serta soal evaluasi dan penyelesaiannya. Sedangkan pada buku siswa terdapat materi, Lembar Kerja Praktikum (LKP), contoh soal, dan soal latihan. Buku ajar yang dikembangkan melewati beberapa tahapan untuk mendapatkan buku ajar final atau buku ajar yang digunakan untuk penelitian. Tahapan tersebut seperti yang dijelaskan di bawah ini: Tahap terakhir dalam pengembangan buku ajar Fisika, yaitu tahap Uji Coba. Tahap Uji Coba ini dilakukan dalam satu set kegiatan meliputi beberapa uji coba, yaitu: a) evaluasi ahli; b) uji coba kelompok terbatas; dan c) main field testing; Buku Ajar Draf I Pada buku ajar draf 1, peneliti telah merancang buku ajar berbasis Problem Based Learning dengan materi Elastisitas dan Hukum Hooke yang belum divalidasi dan belum dinilai. Buku ajar yang dikembangkan adalah yang paling awal dan sangat sederhana. Buku ajar dikembangkan menggunakan ms word, photoshop, dan photoscape. Buka ajar dikembangkan terdiri dari dua buku yaitu: buku siswa dan buku guru.

Buku Ajar Draf II Pada buku ajar draf II ini merupakan perbaikan dari buku ajar draf I sebelumnya. buku ajar direvisi dari saran dan masukan melalui para ahli validator yang diberikan pada buku ajar draf 1 tadi, selanjutnya penulis melakukan beberapa hal yang harus diperbaiki sebelum melakukan penelitian. Buku ajar dikembangkan menggunakan ms word, photoshop, dan photoscape. Setelah buku ajar draf 2 selesai dirancang, selanjutnya peneliti memberikan buku ajar untuk divalidasi oleh ahli materi dan media untuk memberikan saran dan masukan terhadap buku ajar yang dirancang.

Hasil Buku Ajar Final Dari buku ajar draf 1 dan draf 2 yang telah dinilai dan diperbaiki oleh validator ahli, dosen Fisika, dan guru Fisika akhirnya didapat buku ajar final yang dapat digunakan dalam penelitian. Buku ajar dikembangkan menggunakan ms word, photoshop, dan photoscape. Buku ajar draf final ini adalah buku ajar yang akan digunakan dalam penelitian di SMA Negeri 2 Lubuklinggau. Berikut buku ajar final dapat dilihat pada gambar 2. 


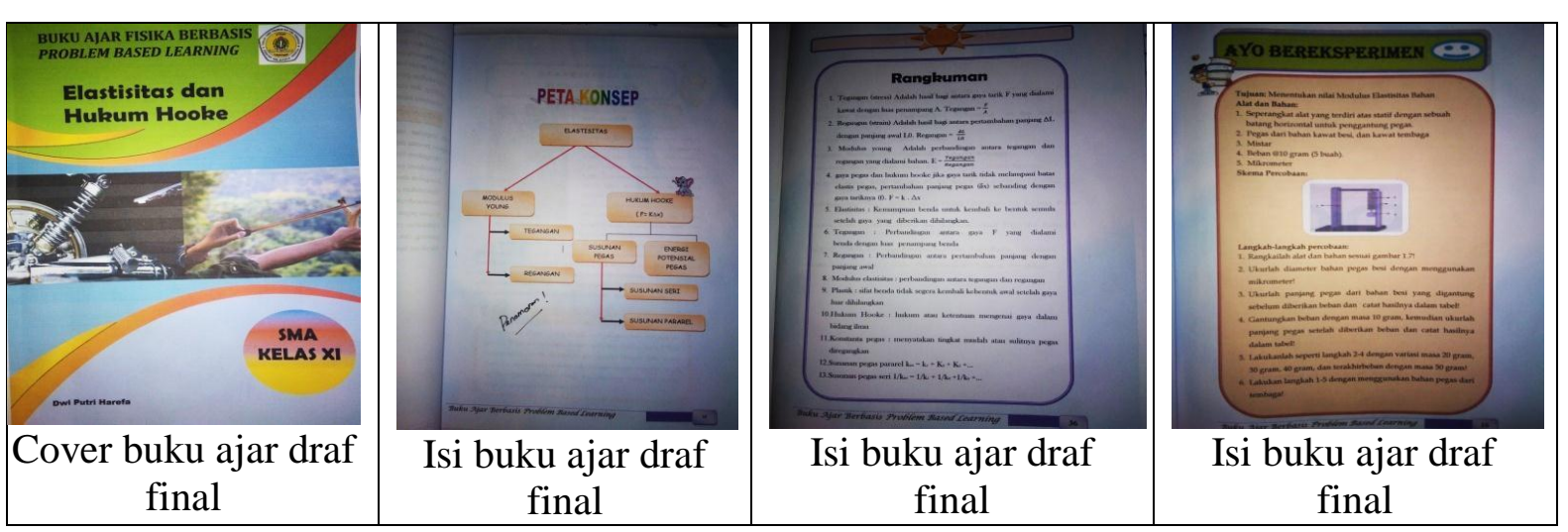

Gambar 2. Draf buku ajar Final

Setelah melewati beberapa kali revisi, pada buku ajar final ini penulis tetap memberikan buku ajar kepada para ahli untuk dinilai. Pada buku ajar final, ahli materi dan media memberikan nilai yang sangat baik dan tanpa ada yang harus diperbaiki. Sedangkan untuk ahli bahasa juga memberikan nilai yang sangat baik, tetapi hanya ada satu kata pengetikan yang kurang tepat. Untuk ahli bahasa menyarankan tidak melakukan perbaikan yang banyak hanya merevisi pengetikan kata yang salah.

\section{a. Kelayakan Buku Ajar}

Kelayakan dari buku ajar Fisika berbasis Problem Based Learning ini dilihat dari hasil validasi yang dilakukan kepada beberapa ahli dan dari beberapa aspek. Evaluasi ahli dilakukan untuk menyempurnakan buku ajar yang dikembangkan dari segi materi, media, dan bahasa. Sebagai ahli materi dipilih seorang dosen prodi Fisika yaitu bapak Yaspin Yolanda, M.Pd.Si. Sebagai ahli media dipilih dosen prodi Fisika yaitu bapak Dodik Mulyono, M.Pd. Sedangkan sebagai ahli bahasa dipilih seorang dosen prodi bahasa Indonesia yaitu ibu Rusmana dewi, M.Pd. Ketiga validator ini dipilih melalui rekomendasi dari pihak LP4MK STKIP-PGRI Lubuklinggau untuk memberikan penilaian dan saran terhadap buku ajar yang peneliti kembangkan. Instrumen yang digunakan adalah angket terbuka, berdasarkan indikator dan saran yang dibutuhkan dalam mengembangkan buku ajar berbasis Problem Based Learning. Secara rinci peneliti uraikan sebagai berikut.

Validasi materi dilakukan dosen Fisika STKIP PGRI Lubuklinggau. Validasi materi yang dilakukan kepada dosen Fisika yaitu bapak Yaspin Yolanda, M.Pd.Si sebanyak tiga kali. Hal ini dimaksudkan untuk memaksimalkan dan agar materi dalam buku ajar yang dikembangkan semakin baik. Hasil tanggapan ahli pada validasi komponen materi yang kedua terdapat peningkatan yaitu mendapatkan skor 42. Dari hasil analisis validasi yang kedua ini termasuk dalam kategori Sangat Baik yaitu dengan persentase 42. Bapak Yaspin 
Yolanda, M.Pd.Si memberikan beberapa saran untuk perbaikan buku ajar pada validasi yang kedua yaitu perbaiki LKP percobaan pertama, perhatikan penulisan dan konsistensi penulisan rumus, serta perbaiki beberapa fase menalar dan mengamati.

Validasi Kedua adalah hasil dari validasi tata bahasa. Validasi tata bahasa dilakukan kepada ahli bahasa yaitu dosen bahasa indonesia, ibu Rusmana Dewi, M.Pd. Validasi yang dilakukan dari segi tata bahasa ini hanya dilaksanakan satu kali. Hasil tanggapan dari validasi komponen tata bahasa mendapatkan skor 18. Dari hasil analisis validasi ini termasuk dalam kategori baik yaitu dengan persentase 18 dan buku ajar yang dikembangkan layak digunakan dari tata bahasa dengan tetap adanya beberapa revisi sesuai dengan saran. Dr.Rusamana Dewi, M.Pd memberikan beberapa saran untuk perbaikan buku.

Validasi ketiga adalah hasil dari validasi media atau desain. Validasi media atau desain dilakukan kepada ahli media desain yang ada di STKIP PGRI Lubuklinggau yaitu salah satu dosen matematika yang menjadi ahli media di STKIP PGRI Lubuklinggau yaitu Dr. Dodik Mulyono, M.Pd. Hasil tanggapan dari validasi komponen tata bahasa mendapatkan skor 28. Dari hasil analisis validasi ini termasuk dalam kategori baik yaitu dengan persentase 28 dan buku ajar yang dikembangkan layak digunakan dari segi media desain dengan tetap adanya beberapa revisi sesuai dengan saran. Berdasarkan hasil penilaian tahap validasi oleh para ahli yang telah dilakukan terhadap buku ajar berbasis Problem Based Learning yang telah diuraikan di atas menunjukkan maka kevalidan buku ajar yang dikembangkan persentasenya mencapai 28 yang termasuk dalam kategori baik sehingga buku ajar yang dikembangkan layak untuk digunakan dalam kegiatan belajar mengajar dengan tetap melakukan perbaikan sesuai dengan saran dan komentar yang diberikan dan buku ajar berbasis Problem Based Learning dapat digunakan untuk tahap selanjutnya yaitu uji coba yang akan dilaksanakan di SMA Negeri 2 Lubuklinggau. Hasil validasi yang telah dilaksanakan oleh ketiga ahli dapat dilihat pada tabel 2.

Tabel 2. Rekapitulasi Tanggapan Ketiga Ahli

\begin{tabular}{cccc}
\hline No & Validator & $\begin{array}{c}\text { Hasil } \\
\text { Penilaian }\end{array}$ & Kategori \\
\hline 1 & Validasi Materi & 42 & Sangat Baik \\
\hline 2 & Validasi Media & 28 & Baik \\
\hline 3 & Validasi Tata Bahasa & 18 & Baik \\
\hline & Total & 88 & Baik
\end{tabular}

\section{b. Kepraktısan Buku Ajar}

Kepraktisan bahan ajar fisika di ujikan dengan melewati beberapa uji coba. Uji coba yang dilakukan adalah uji coba melalui tahapan uji coba kelompok terbatas dan main field Puplished at https://ojs.stkippgri-lubuklinggau.ac.id/index.php/SJPIF 
testing untuk melihat kepraktisan lembar kerja siswa yang dilaksanakan di SMA Negeri 2 Lubuklinggau. Angket yang diberikan untuk penilaian bahan ajar fisika berbasis Problem Based Learning indikatornya sama seperti lembar wawancara yaitu, 1) kemenarikan bahan pembelajaran Fisika, 2) keterbacaan materi, dan 3) kemudahan pemahaman materi. Dari angket respon siswa yang telah diberikan mendapatkan nilai 34,14 termasuk dalam kategori sangat baik yang dikembangkan sudah baik dan sesuai dengan yang mereka inginkan. Berdasarkan hasil angket kelompok terbatas dan main field testing yang diperoleh, dapat disimpulkan bahwa respon siswa terhadap buku ajar berbasis Problem Based Learning adalah sangat baik dengan persentase 36,7. Jadi persentase keseluruhan dari validasi awal sampai akhir adalah 36,7.

Dari uji coba yang dilakukan terhadap siswa dengan menggunakan angket didapatkan hasil data kepraktisan lembar kerja siswa Fisika berbasis berbasis scientific materi Elastisitas dan Hukum Hooke di kelas XI SMA Negeri 2 Lubuklinggau yaitu cukup praktis sehingga dapat digunakan di SMAN 2 Lubuklinggau.

Tabel 3. Hasil Angket Uji Main Field Testing

\begin{tabular}{ccc}
\hline Kode Siswa & Skor & Keterangan \\
\hline S-1 & 32 & Sangat Baik \\
\hline S-2 & 36 & Sangat Baik \\
\hline S-3 & 40 & Sangat Baik \\
\hline S-4 & 40 & Sangat Baik \\
\hline S-5 & 36 & Sangat Baik \\
\hline S-6 & 37 & Sangat Baik \\
\hline S-7 & 36 & Sangat Baik \\
\hline S-8 & 38 & Sangat Baik \\
\hline S-9 & 35 & Sangat Baik \\
\hline Jumlah & 330 \\
\hline Rata-rata & 36,7 \\
\hline
\end{tabular}

Tabel 4. Kategori Konversi Skor Aktual Menjadi Nilai Skala 5

\begin{tabular}{cccc}
\hline No & Rentang Skor & Nilai & Kategori \\
\hline 1 & $\mathrm{X}>20,4$ & $\mathrm{~A}$ & Sangat Baik \\
\hline 2 & $16,8<\mathrm{X} \leq 20,4$ & $\mathrm{~B}$ & Baik \\
\hline 3 & $13,2<\mathrm{X} \leq 16,8$ & $\mathrm{C}$ & Cukup Baik \\
\hline 4 & $4,2<\mathrm{X} \leq 13,2$ & $\mathrm{D}$ & Kurang Baik \\
\hline 5 & $\mathrm{X} \leq 9,6$ & $\mathrm{E}$ & Sangat Kurang Baik \\
\hline
\end{tabular}

Berdasarkan hasil angket kelompok terbatas dan main field testing yang diperoleh, dapat disimpulkan bahwa respon siswa terhadap buku ajar berbasis Problem Based Learning adalah sangat baik dengan persentase 36,7. Jadi persentase keseluruhan dari validasi awal sampai akhir adalah 36,7. 
Tabel 5. Hasil Rekapitulasi Penilaian Angket Kepraktisan

\begin{tabular}{cccc}
\hline No. & Subjek & $\begin{array}{c}\text { Hasil } \\
\text { penilaian }\end{array}$ & Ketegori \\
\hline 1 & Uji Kelompok terbatas & 24,7 & Sangat Baik \\
\hline 2 & Uji Main Field Testing & 36,7 & Sangat Baik \\
\hline & Total & 61,7 & \\
\hline
\end{tabular}

Uji coba kepraktisan dilakukan karena sesuai dengan model pengembangan yang digunakan mengenai bahan ajar Fisika berbasis Problem Based Learning materi Elastisitas dan Hukum Hooke. Angket yang diberikan siswa dianjurkan untuk mengisi saran atau komentar di tempat yang telah disediakan. Dalam hal ini tidak ada saran dan komentari dari siswa kelas XI MIA 2 SMAN 2 Lubuklinggau.

\section{KESIMPULAN DAN SARAN}

Berdasarkan hasil penelitian dengan menggunakan bahan ajar fisika berbasis Problem Based Learning pada materi elastistas dan hukum hooke di SMA Negeri 2 Lubuklinggau tahun pelajaran 2020/2021, dapat disimpulkan bahwa:

Peneliti melakukan proses pengembangan bahan ajar berbasis Problem Based Learning pada materi Elastisitas dan Hukum Hooke. penelitian ini menggunakan model pengembangan milik Sugiyono. Hasil penilaian validator terhadap kualitas bahan ajar berbasis Problem Based Learning pada komponen kelayakan materi memiliki persentase sebesar 42, sementara itu untuk komponen media memiliki persentase sebesar 28 dan untuk komponen kebahasaan memiliki persentase sebesar 18. Persentase keseluruhan komponen adalah 88 sehingga bahan ajar berbasis Problem Based Learning dikatakan valid dan memenuhi kriteria baik. Persentase keseluruhan komponen bahan ajar yang divalidasi oleh para ahli adalah 88 sehingga bahan ajar berbasis Problem Based Learning dikatakan valid dan memenuhi kriteria baik. Persentase keseluruhan respon siswa terhadap bahan ajar berbasis Problem Based Learning adalah 81,11 sehingga bahan ajar dikatakan praktis dan memenuhi kriteria setuju atau positif. Dan persentase hasil tes ulangan harian $90 \%$ siswa yang memperoleh nilai di atas 71 ada 7 siswa dan 2 siswa nilainya dibawah 71 dari sepuluh butir soal tes sehingga bahan ajar dikatakan praktis. Oleh karena itu, bahan ajar berbasis Problem Based Learning materi Elastisitas dan Hukum Hooke tahun pelajaran 2020/2021 dapat dikatakan valid, dan praktis.

\section{Saran}

Adapun saran pemanfaatan dan pengembangan produk lebih lanjut adalah sebagai berikut:

Puplished at https://ojs.stkippgri-lubuklinggau.ac.id/index.php/SJPIF 
1. Peneliti menyarankan bahan ajar berbasis Problem Based Learning dapat digunakan dalam dan membantu guru dalam menjelaskan pembelajaran materi Elastisitas dan Hukum Hooke karena telah mendapat penilaian sangat baik dan layak digunakan.

2. Bahan ajar berbasis Problem Based Learning bisa dikolaborasikan dengan model pembelajaran yang lain selama masih menyertakan komponen Problem Based Learning.

\section{DAFTAR PUSTAKA}

Aji, S., Hudha, M. N., \& Rismawati, A. (2017). Pengembangan modul pembelajaran fisika berbasis problem based learning untuk meningkatkan kemampuan pemecahan masalah fisika. SEJ (Science Education Journal), 1(1), 36-51.

Ariani, T., \& Suanti, W. (2016). Efektivitas Penggunaan Model Pembelajaran Problem Based Learning (PBL) Pada Pembelajaran Fisika Siswa Kelas VIII SMP Negeri 2 Lubuklinggau Tahun Pelajaran 2015/2016. Jurnal Inovasi dan Pembelajaran Fisika, 3(2), 1-6.

Aryansi, D., \& Yolanda, Y. (2020). Pengembangan Buku Ajar Fisika Berbasis Kotekstual pada Materi Medan Magnetik Siswa Kelas XII SMA Negeri 2 Muara Beliti. SILAMPARI JURNAL PENDIDIKAN ILMU FISIKA, 2(2), 107-118.

Fatmawati, Agustina. 2016. Pengembangan Perangkat Pembelajaran Konsep Pencemaran Lingkungan Menggunakan Model Pembelajaran Berdasarkan Masalah Untuk Sma Kelas X. EduSains. 4 (2), 97.

Hoellwarth, C., Moelter, M. J., \& Knight, R. D. (2005). A direct comparison of conceptual learning and problem solving ability in traditional and studio style classrooms. American Journal of Physics, 73(5), 459-462.

Komariah, N., Mujasam, M., Yusuf, I., \& Widyaningsih, S. W. (2019). Pengaruh Penerapan Model PBL Berbantuan Media Google Classroom Terhadap Hots, Motivasi dan Minat Peserta Didik. Silampari Jurnal Pendidikan Ilmu Fisika, 1(2), 102-113.

Lorenza, Y., Sasmita, P. R., \& Amalia, S. (2019). Pengaruh Model Pembelajaran Inkuiri Terbimbing Berbantukan Alat Peraga Sederhana Terhadap Hasil Belajar Fisika Peserta Didik. Silampari Jurnal Pendidikan Ilmu Fisika, 1(2), 87-93.

Nini, Wa Ode, dkk. 2015. Efektivitas Penerapan Model Pembelajaran Kooperatif Tipe Think Pair Share Terhadap Hasil Belajar Matematika Materi Pokok Statistika Pada Siswa Kelas IX SMP Negeri 2 Kendari. Jurnal Penelitian Pendidikan Matematika 3(1), 153166.

Nur, Anis. 2015. Penerapan Model Pembelajaran Generatif Untuk Meningkatkan Hasil Belajar Fisika Siswa Kelas XII IPA1 SMA Negeri 9 Makasar. Jurnal Pendidikan Fisika 3(1):1-13.

Permendikbud. 2014. No 59 dan 103 Tentang Pembelajaran pada Pendidikan Dasar dan Menengah.".

Prastowo, Andi. 2014. Pengembangan Bahan Ajar Tematik Tinjauan Teoretis Dan Praktis. Jakarta : Kencana.

Puplished at https://ojs.stkippgri-lubuklinggau.ac.id/index.php/SJPIF 
Setyosari Punaji. 2013. Metode Penelitian Dan Pengembangan Edisi Keempat. Jakarta: Prenadamedia Group.

Sugiyono. 2012. Metode Penelitian Pendidikan Pendekatan Kuantitatif, Kualitatif Dan R\&D. Bandung : Alfabeta.

Sukerni, Putu. 2014. Pengembangan Buku Ajar Pendidikan IPA Kelas IV Semester 1 SD No.4 Kaliuntu Dengan Model Dick And Carey. Jurnal Pendidikan Indonesia 3(1), 386396.

Susanto, Ahmad. 2013. Teori Belajar Dan Pembelajaran Di Sekolah Dasar. Jakarta: Prenadamedia Group.

Susilo, Agus, dkk. 2016. Pengembangan Modul Berbasis Pembelajaran Saintifik Untuk Peningkatan Kemampuan Mencipta Siswa Dalam Proses Pembelajaran Akuntansi Siswa Kelas XII SMA N 1 Slogohimo 2014. Jurnal Ilmu Pendidikan Sosial 26(1), 5056.

Yerimadesi, dkk,. 2016. Pengembangan Modul Kesetimbangan Kimia Berbasis Pendekatan Saintifik Untuk Kelas XI SMA/MA. Journal Of Sainstek 8(1), 85-97. 